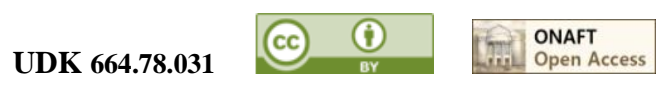

DOI: https://doi.org

S. Sots, PhD of Technical Science, Associate Professor, E-mail: sotsserega@ gmail.com https://orcid.org/0000-0002-3267-2384, ResearcherID: G-9192-2019

Y. Chumachenko, PhD of Technical Science, Associate Professor, E-mail: yuriy. chumachenko@ gmail.com https://orcid.org/0000-0003-2810-228X, ResearcherID: I-2122-2016

I. Kustov, PhD of Technical Science, Associate Professor, E-mail: i.kustov1988@ gmail.com https://orcid.org/0000-0001-7632-1626, ResearcherID: I-3249-2016

Y. Kuzmenko, PhD of Technical Senior Lecturer, E-mail: kuzmenko.y89@ gmail.com https://orcid.org/0000-0001-8693-643X, ResearcherID: G-7831-2019

Odessa National Academy of Food Technologies, 112, Kanatna Str., Odessa, 65039, Ukraine

Tel. +380487124013

\title{
PRODUCTION OF FLAKED PRODUCTS FROM NAKED OATS. PHYSICAL PROPERTIES OF THE FLAKES
}

\begin{abstract}
Flakes and instant groats products have become increasingly prolific in recent decades among groats products. The interest of consumers in this type of groats and groats products is primarily connected to their ability to be quickly prepared and good food and flavoring properties compared with traditional groats. Due to their balanced amino acid composition, the presence of mucous substances unique vitamin content, most of groats can be attributed to the products of dietary and restorative nutrition.

In the given article the existing technologies of hulled oats grain processing into groats products were analyzed. The possibilities of using new breeding varieties of oats to improve existing technologies were analyzed. Advantages using naked oat varieties for the production of groats and flakes were considered.

It was found that the technologically expedient moisture content of pearled naked oats groats before steaming is $17-$ $17.5 \%$. After steaming groats with this moisture yield of flaked groat estimated to range between 84,3-93,6\%.

For substantiation of modes of preparing pearled groats to flaking determining of its impact on physical properties of the flaked groats were conducted. Flaked products obtained from naked oats characterized by high uniformity, however by fractional composition are smaller compared with control samples. The main their percentage (about 60-70\%), obtained by overflow of sieves $\varnothing 3,0 \mathrm{~mm}$ and $\varnothing 1,5 \mathrm{~mm}$.

Thickness of obtained in the studied modes flaked products is in the range 0,4-1,1 mm. Flaked products obtained from naked oats by steaming oats groats with moisture content $19.1 \%$ by indicator of thickness characterized as flaked groats for which the characteristic thickness is 0.7 to $0.9 \mathrm{~mm}$. Mode of steaming groats at vapor pressure of $0.15 \mathrm{MPa}$ with moisture content $17.5 \%$ allows producing flaked products which correspond by the value of thickness of the control of classical oat flakes 0,4-0,9 mm. Decreasing moisture content of groats before steaming to $15.4 \%$ allows producing thin flakes, values of thickness of which in the range of 0.4-0.7 mm.

Except thickness, strength of flakes also depends on mass fraction of moisture. For flakes with higher humidity inherent strength is greater compared to a product with low humidity. The final moisture of oat flakes is normalized by regulations and must not exceed $12.0 \%$. Waterheat treatment of pearled groats with further its flaking reduces the proportion of ashes of flaked products from 1.8 to $1.5 \%$.
\end{abstract}

Key words: flaced groats, oats, flakes, steaming, flaking, modes of processing, chemical composition.

\section{Introduction}

Traditionally, at groats plants being processed include seven cereal crops: rice, millet, buckwheat, oats, barley, corn, wheat and also one legume crop - peas. A small proportion constitute groats food products obtained by processing of sorghum, lentils, chickpeas and other.

Wide demands from consumers have rice, buckwheat and oat groats and derivates from its groats products. Flakes and instant groats products have become increasingly prolific in recent decades among groats products. The interest of consumers in this type of groats and groats products is primarily connected to their ability to be quickly prepared and good food and flavoring properties compared with traditional groats.

The nutritional value of grain intended for food production is defined by the chemical composition which is characterized by containing proteins, starches, lipids, fiber, minerals and $\beta$-glucans.

Due to their balanced amino acid composition, the presence of mucous substances unique vitamin content, most of groats can be attributed to the products of dietary and restorative nutrition.

Processing of these crops involves complex energy-intensive operation in technological process. Most types of groats and groats products have low yield and relatively lower nutritional value compared to the unprocessed grain. During dehulling and pearling operations significant part of protein, vitamins, minerals, $\beta$-glucans and dietary fiber which are concentrated in outer layers are also removed $[1 ; 2]$.

\section{Literary review}

Over the centuries, oats (Avena sativa L.) has been an important fodder and food crops. In the XX century it began to gain importance for agricultural production and processing industries.

The global industry uses oats for producing a wide range of food products besides traditional cereal 
flakes, flour, different groats and instant cooking products it is additionally used in the manufacturing of beer, oat milk, ice cream, bread, cookies, baby food products and other high nutritive products for human $[3 ; 4 ; 5]$.

Standard products of processing oats in Ukraine are not crushed oats groat of which during further processing produces flaked groats, flakes "Hercules", "Pelyustkovi". Separate oat products are flakes "Extra" and "Tolokno" (special prepared oats flour). Not crushed oats groats are products derived from whole kernel they are divided into grades by quantitative content of benign and crushed kernel and presence in the product not hulled grain. Flaked groats and all kinds of oats flakes through the passage during their producing additional special treatment can be referred to the instant foods.

Numbers of flakes "Extra" proportional to the size and shape of previously prepared raw materials due to what they have a high uniformity which is provided by passage and overtail of defined number of sieve. "Tolokno" by its properties are very important food product. As stand-alone product "Tolokno" widely used in dietary nutrition. "Tolokno" and different kinds of oat flour due to the absence of gluten as separate products is almost not applicable but in mixtures with wheat flour oats flour widely used in the baking industry in the production of bread bakery and confectionery products and as in improver in other areas of food processing industry [6].

At different stages of processing, especially at the steaming stage decreases the nutritional value of grain and accordingly products of its processing observed decrease in the mass fraction of protein, starch, vitamins etc. By dehulling and pearling of grain formed significant amount of by-products as husking bran and particles of crushed kernels (15-35\%) which are formed by external and internal parts of the oat kernel and reduce the mass fraction of protein, $\beta$-glucans, vitamins, minerals etc., in aggregate with low values of a finished products allows to speak about low efficiency of existing technologies for production modern oriented food.

Imperfection and complexity of processing traditional varieties of oats into food products was a result of the emergence of new, more promising for food and processing industry naked variety of oats (Avena nuda).

The advantage of naked forms of oats is almost total absence of hard floral hulls, which are firmly related to the surface of the grain $(20 \ldots 40 \%$ in hulled oats forms) which greatly improve their technological properties. Naked oats grain has thin and papery hulls which are practically completely separated in the process of harvesting and thrashing of the grain [6,7].

In studies conducted by R.J. Henry and P.S. Kettlewell observed that naked varieties of oats in the production of foodstuffs can fully replace traditional hulled varieties. P. Peltonen-Sainio and others, comparing processing of naked and hulled oats varieties showed that due to necessity of dehulling, and other complex operations in the technological process of processing conventional varieties of oats is significantly more costly than processing of naked varieties of oats [8].

Formylation of the problem

Today, the world is transitioning to less compli cated and more energy-efficient technologies, which allows to obtain products with higher yields and nutritional value. The basis for the creation of food with improved properties is, as a rule, new specially grain. Among such crops, the naked forms of barley and oats can be distinguished. Today the study of processes of naked varieties of cereal crops in food products is very important for the national grain processing industry.

\section{Material and methods}

Samples of naked oats were cultivated and harvested in Kirovograd region, Ukraine in 2017-2018.

Steaming of oats groat was carried out in the laboratory steamer of periodic action VK-30. Specially prepared sample of the studied material was filled in the special cartridge and placed in steamer. With help of the intake and exhaust valves the pressure and time of steaming were regulated. Groat with moisture content of 15 , $17,19 \%$ was steamed at $0,10-0,20 \mathrm{MPa}$ for $5 \mathrm{~min}$ and then sent to the drying stage [9-14] .

Flaking was carried out in the laboratory mill «Nagema» which includes a roller mill with two pairs of rollers $150 \mathrm{~mm}$ length and $220 \mathrm{~mm}$ in diameter. Working gap set $0.3-0.5 \mathrm{~mm}$.

Drying of the flaked groats after flaking were carried out in the laboratory dryer which works on a "fluidized bed". Mode of operation of the dryer (degree of removal of excessive moisture) was regulated by temperature changes drying agent (air) and time of the grain location in the working area of the dryer. Groat and flakes were dried to a moisture content of $14 \%$.

\section{Results of the study and their discussion}

For substantiation of processing modes of pearled groats from naked oats into flakes necessary to determine the effect modes of water heat treatment on yield and quality of flaked products.

The results of research of influence intensity of water heat treatment modes and steaming on yield of flaked groat are presented in table 1 and figure 1.

It was found that the technologically expedient moisture content of pearled naked oats groats before steaming is $17-17.5 \%$. After steaming groats with this moisture yield of flaked groat estimated to range between 84,3-93,6\%. According to the preliminary organoleptic assessment flaked product obtained by this mode described as flakes.

Table 1 - Influence of modes of water heat treatment and steaming on yield of flaked groats

\begin{tabular}{|c|c|c|c|}
\hline \multirow{2}{*}{ Yield of fraction, $\%$} & \multicolumn{3}{|c|}{ Moisture, \% } \\
\hline & 15,4 & 17,5 & 19,1 \\
\hline \multicolumn{4}{|c|}{ The vapor pressure of $0.10 \mathrm{MPa}$} \\
\hline Flaked groats & 83,4 & 89,4 & 89,2 \\
\hline Husking bran & 16,6 & 10,6 & 10,8 \\
\hline \multicolumn{4}{|c|}{ The vapor pressure of $0.20 \mathrm{MPa}$} \\
\hline Flaked groats & 87,0 & 93,1 & 93,4 \\
\hline Husking bran & 13,0 & 6,9 & 6,6 \\
\hline
\end{tabular}


Decreasing moisture content of pearled groat to $15.4 \%$ does not allow to change of physico-chemical and technological properties in full volume which is indicated by significant amount of husking ban which formed by flaking. Significant amount of husking ban indicates insufficient plastic properties of pearled groats. In addition, by flaking of pearled groats prepared at this mode from flakes breaking away parts and the end product is characterized by asymmetric shape. Increasing humidity to $19.1 \%$ allows increasing the yield of flaked groats however excessive humidity of groats before steaming results in strengthening of groats and losses of its plastic properties so flakes obtained in this mode for organoleptic assessment and character the surface are flaked groats.

It was found that the technologically expedient moisture content of pearled naked oats groats before steaming is $17-17.5 \%$. After steaming groats with this moisture yield of flaked groat estimated to range between $84,3-93,6 \%$. According to the preliminary organoleptic assessment flaked product obtained by this mode described as flakes.

Decreasing moisture content of pearled groat to $15.4 \%$ does not allow to change of physico-chemical and technological properties in full volume which is indicated by significant amount of husking ban which formed by flaking. Significant amount of husking ban indicates insufficient plastic properties of pearled groats. In addition, by flaking of pearled groats prepared at this mode from flakes breaking away parts and the end product is characterized by asymmetric shape. Increasing humidity to $19.1 \%$ allows increasing the yield of flaked groats however excessive humidity of groats before steaming results in strengthening of groats and losses of its plastic properties so flakes obtained in this mode for organoleptic assessment and character the surface are flaked groats.

In the application of the recommended modes of preparing pearled groats to flaking yield of flaked products at 1.7-1.9 times higher than yield of flakes obtained from hulled oat which indicates the high potential of investigated naked oats variety "Salomon" for the production of cereal flakes.

For substantiation of modes of preparing pearled groats to flaking determining of its impact on physical properties of the flaked groats were conducted. Quality of oat flakes except nutritional value, also evaluate by

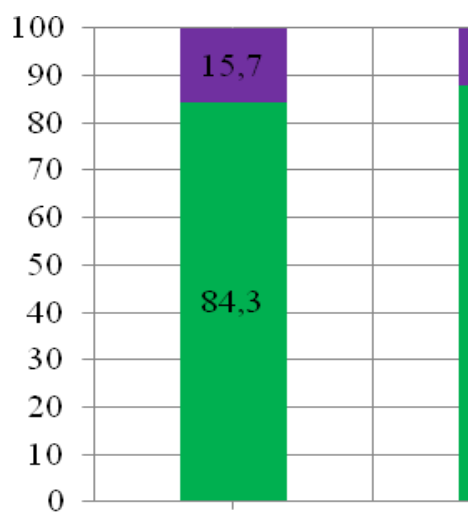

60

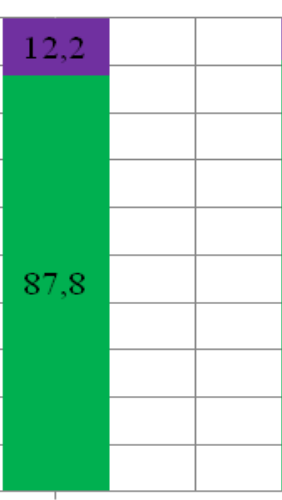

120

$\square$ flaced groats $\square \quad$ particles of crushed groats

physical properties which include geometric characteristics and strength.

The strength and thickness are interrelated parameters - flakes with less thickness are usually characterized by low strength and at different stages of technological process are able to destruction that increases proportion of husking bran and reduces the nutritional value of the product.

Traditionally cereal flakes made from different types of crops characterized by thickness $0,2-1,0 \mathrm{~mm}$. For oats flaked products characteristic values of the thickness is of up to $0.5 \mathrm{~mm}$ for flakes "Hercules" and 0.7-0.9 mm gor flaked groats. Except thickness, strength of flakes also depends on mass fraction of moisture. For flakes with higher humidity inherent strength is greater compared to a product with low humidity. The final moisture of oat flakes is normalized by regulations and must not exceed $12.0 \%$.

Fractional composition of flakes depends on the size characteristics of processed raw materials. Technological process of processing oats flakes "Extra" provides special cutting operations of groats which allows obtaining three numbers flakes for particle size. For flakes "Hercules" and "Pelyustkovi» which are not divided into numbers and produced from whole groats characteristic are greater dimensional characteristics of the finished product.

Flaked products obtained from naked oats characterized by high uniformity, however by fractional composition are smaller compared with control samples (fig. 2, fig. 3). The main their percentage (about 60$70 \%$ ), obtained by overflow of sieves $\varnothing 3,0 \mathrm{~mm}$ and $\varnothing 1,5 \mathrm{~mm}$. Closest to control samples are flaked products obtained by steaming of groats from preliminary moisture content $17.5 \%$ (duration of steaming 180-300 s). In this mode the amount of flakes obtained by overflow of sieves $\varnothing 6,0 \mathrm{~mm}$ and $\varnothing 3,0 \mathrm{~mm}$ include $78-80 \%$. The proportion of small fraction obtained by overflow of sieve $\varnothing 1,5 \mathrm{~mm}$ include $18-19 \%$. Flaked products obtained from naked oats by steaming oats groats with moisture content $19.1 \%$ characterized by fractional composition characteristic for classical flaked groats.

Thickness of obtained in the studied modes flaked products is in the range $0,4-1,1 \mathrm{~mm}$. Flaked products obtained from naked oats by steaming oats groats

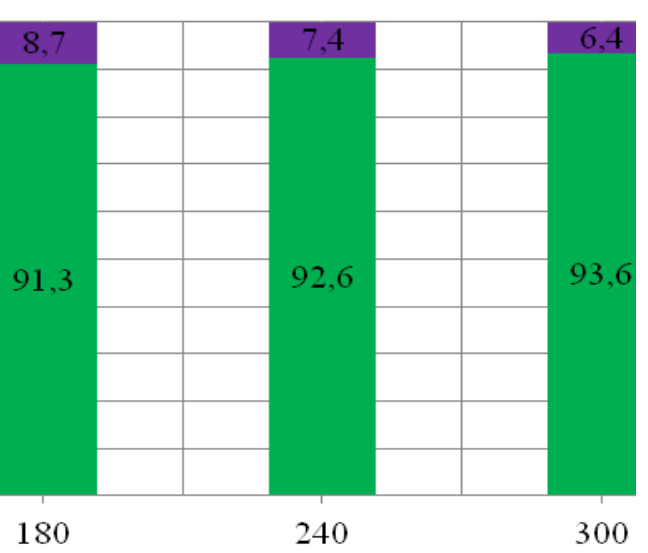

Fig 1. - Influence of modes of water heat treatment and steaming on yield of flaked groats, $\mathrm{P}=0,15 \mathrm{MPa}, \mathrm{W}=17,5 \%$ 


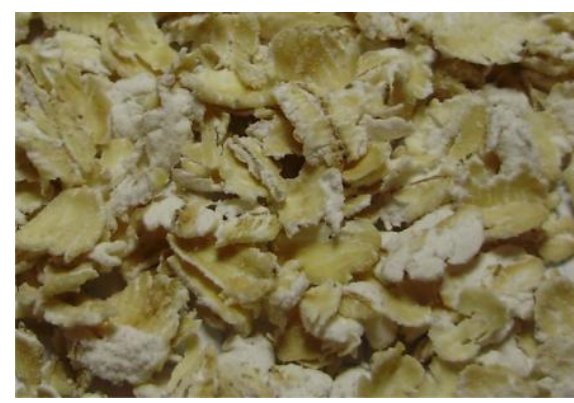

a)

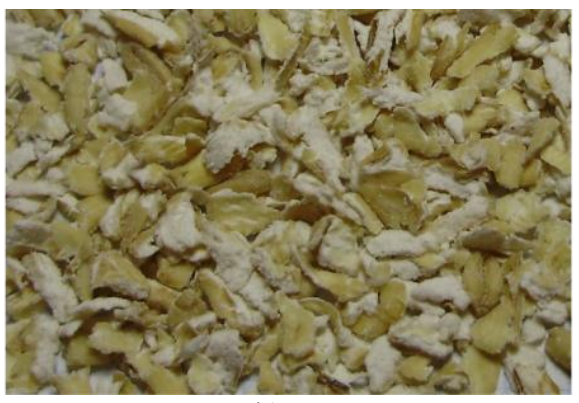

b)

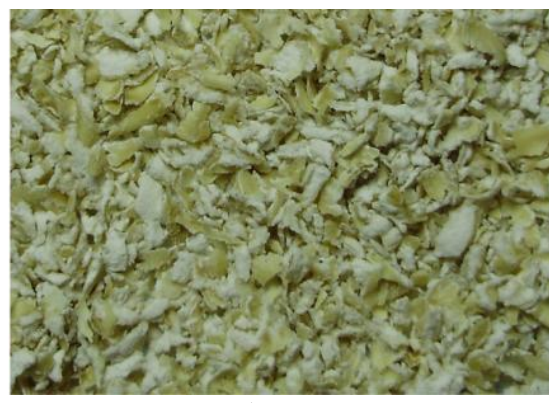

c)

Fig 2. - General view of fractions of flaked oat products $(P=0,15 \mathrm{MII}, \mathrm{W}=17,5 \%, t=180 \mathrm{~s})$ : a) large; b) medium; c) small

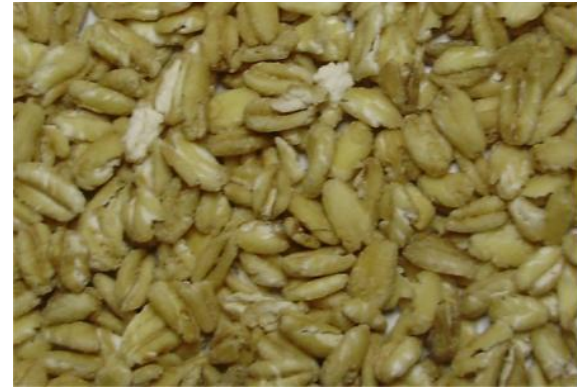

a)

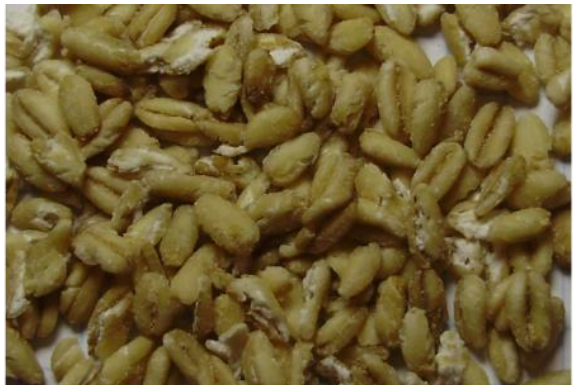

b)

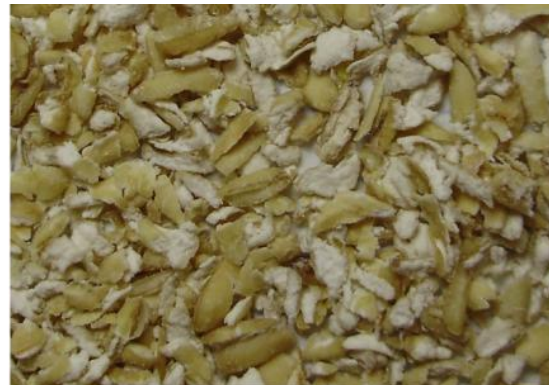

c)

Fig 3. - General view of fractions of flaked oat products $(P=0,15 \mathrm{M \Pi a}, \mathrm{W}=19,1 \%, t=180 \mathrm{~s})$ : a) large; b) medium; $c$ ) small

with moisture content $19.1 \%$ by indicator of thickness characterized as flaked groats for which the characteristic thickness is 0.7 to $0.9 \mathrm{~mm}$. Mode of steaming groats at vapor pressure of $0.15 \mathrm{MPa}$ with moisture content $17.5 \%$ allows producing flaked products which correspond by the value of thickness of the control of classical oat flakes 0,4-0,9 mm. Decreasing moisture content of groats before steaming to $15.4 \%$ allows producing thin flakes, values of thickness of which in the range of 0.4-0.7 mm.

Greatest strength are characterized rolled products obtained by steaming of groats with the previous moisture content $19.1 \%$ which are characterized the largest thickness. Flaked products produced during steaming groats with the previous moisture content $17.5 \%$ characterized by strength characteristic for control samples of oat flakes.

Based on obtained data it can be concluded that regulation modes of water heat treatment of groats and duration of steaming by processing of naked oats is possible receive two types of flaked products - flakes and flaked groat which by their physical properties are close to classical flaked oat products.

At the next stage of research effect of the studied modes of water heat treatment on changing chemical composition of flaked products were determined. The most important components of the chemical composition that formed nutritional value of the product - the mass fraction of ash, protein, starch, fat, $\beta$-glucans and vitamins were determined. As a control samples used oats flakes "Super Hercules №1», made by TM "Dobrodija" (Control 1) and flakes "Extra" made by TM "Hercules" (Control 2).
Analysis of literature data shows that depending on the method of treatment and appointment ash values in oat flakes may vary in the range of 1.54 to $2.03 \%$ In our country, according to current regulations indicator of ash content of traditional oat flakes "Hercules" and "Pelyustkovi» is guarantee and depending on product limited and is not more than $1.9 \%$ for "Pelyustkovi» and $2.1 \%$ for "Hercules". Ash content of classical flakes produced in plant conditions is located in regulated by standard range and include $1,7 \%$ for "Super Hercules №1» and $1.8 \%$ for flakes "Extra".

Water heat treatment of pearled groats with further its flaking reduces the proportion of ashes of flaked products from 1.8 to $1.5 \%$. The ash content of samples obtained by flaking pearled groats with initial moisture content $17 \%$ and 19 steamed with vapor pressure of $0.15 \mathrm{MPa}$ include $1.6-1.8 \%$ which is located within values of ash in classical flakes therefore the use of these modes of steaming allows to produce flakes from naked oats with mass fraction of ash which regulated by standard.

By this mode of preparation pearled groats to flaking mass fraction of protein in flaked products include $11,7-13,2 \%$ fat - 6,0-6,3\% starch - from 58-62\%, $\beta$-glucans - 5,1-5,7\%, vitamin B1 - 0,52-0,55 mg / $100 \mathrm{~g}$, B2 - 0,12-0,15 mg / $100 \mathrm{~g}$.

\section{Conclusion}

Defined mode of processing allows producing flaked products during further processing of pearled groats which are characterized by regulated ash content and by content of other biologically active substances match to traditional products made from hulled grains. 


\section{REFERENCES}

1. Chakraverty, A., Mujumdar, A.S., Raghavan, V., Ramaswamy, H.S. (Eds.) (2003). Handbook of postharvest technology-Cereals, fruits, vegetables, teas and spices. USA Boca Raton: CRC Press.

2. Kent, N.L., Evers, A.D. (1994) Kent's Technology of Cereals, 4th edn., Woodhead Publishing Limited

3. Ryan, L., Thondre, P.S., Henry, C.J.K. (2011) Oat-based breakfast cereals are a rich source of polyphenols and high in antioxidant potential. J Food Compos Anal, 24, 929-934.

4. Rules for organizing and operating the process at large plants. - K., 1998. -164 p.

5. Shutenko, E.I. Large-scale production technology: training Manual [Text] / E.I. Shutenko, S.M. Sots. - K.: Education. Ukrein, 2010. - 272 c.

6. Henry, R., \& Kettlewell, P. (Eds.). (2012). Cereal grain quality. Springer Science \& Business Media.

7. Peltonen-Sainio, P., Kirkkari, A. M., \& Jauhiainen, L. (2004). Characterising strengths, weaknesses, opportunities and threats in producing naked oat as a novel crop for northern growing conditions.

8. Henry, R., \& Kettlewell, P. (Eds.). (2012). Cereal grain quality. Springer Science \& Business Media.

9. Conciatori, A., Stefanis, E. D., Redaelli, R., \& Sgrulletta, D. (2000). Chemical characterization of some kernel traits in naked oat genotypes. Journal of Genetics \& Breeding, 54(4), 299-302.

10. Welch, R. W. (Ed.). (2012). The oat crop: production and utilization. Springer Science \& Business Media.

11. Gajdošová, A., Petruláková, Z., Havrlentová, M., Červená, V., Hozová, B., Šturdik, E., \& Kogan, G. (2007). The content of water-soluble and water-insoluble $\beta$-D-glucans in selected oats and barley varieties. Carbohydrate polymers, 70(1), 46-52.

12. Kaukovirta-Norja, A. Germination: a means to improve the functionality of oat [Text] / A. KaukovirtaNorja, A. Wilhelmson, K. Poutanen // Agricultural and food science. - 2004. - vol. 13, № 1-2. - P. 100112.

13. Hager, A.S. Gluten free beer -A review. [Text] / A.S. Hager, J.P. Taylor, D.M. Waters et al. // Trends in Food Science \& Technology. - 2014. - vol. 36, № 1. - P. 44 - 54.

14. Schnitzenbaumer, B. Implementation of commercial oat and sorghum flours in brewing [Text] / B. Schnitzenbaumer, J. Kaspar, J. Titze, et al. // European Food Research and Technology. - 2014. vol. 238, № 3. - P. $515-525$.

\section{УДК 664.78.031}

С.М. Соц, канд. техн. наук, доцент, E-mail: sotsserega@ gmail.com https://orcid.org/0000-0002-3267-2384, ResearcherID: G-9192-2019

Ю.Д. Чумаченко, канд. техн. наук, доцент, E-mail: yuriy. chumachenko@ gmail.com https://orcid.org/0000-0003-2810-228X, ResearcherID: I-2122-2016 I.O. Кустов, канд. техн. наук, доцент, i.kustov1988@gmail.com https://orcid.org/0000-0001-7632-1626, ResearcherID: I-3249-2016

Ю.Я. Кузьменко, канд. техн. наук, ст. викладач, kuzmenko.y89@ gmail.com https://orcid.org/0000-0001-8693-643X, ResearcherID: G-7831-2019

${ }^{1}$ Одеська національна академія харчових технологій, вул. Канатна, 112, Одеса, 65039, Украӥна

\section{ВИРОБНИЦТВО ПЛЮЩЕНИХ ПРОДУКТІВ 3 ГОЛОЗЕРНОГО ВІВСА. ФІЗИЧНІ ВЛАСТИВОСТІ ПЛАСТІВЦІВ}

\footnotetext{
Анотація

Пластівці та продукти швидкого приготування з круп в останні десятиліття все більше користуються попитом. Інтерес споживачів до изього виду крупи та продукиї взагалі пов'язаний, насамперед, з їх здатністю швидко готуватись та добрими харчовими, та смаковими властивостями порівнянно з традиційними крупами. Завдяки збалансованому амінокислотному складу, наявності багатьох вітамінів у складі більшість круп можна віднести до продуктів функиіонального харчування, щуо робить їх більш затребуваними.

В даній статті проаналізовані існуючі технологї переробки зерна вівса у крупу. Були проаналізовані можливості використання нових сортів вівса для вдосконалення існуючих технологій. Розглянуто переваги використання голозерних сортів вівса для виробництва круп та пластівців.

Встановлено, щчо технологічно дочільна частка вологи в шліфованому ядрі голозерного вівса перед пропарюванням становить 17-17,5\%. Після пропарювання крупи з иією вологістю пластівці вихід плющеного ядра складає в межах 84,3-93,6\%.

Для обтрунтування режиму ВТО проводили визначення його впливу на фізичні властивості отриманих досліджуваних режимах плющених продуктів.

Плющені продукти отримані із голозерного вівса характеризуються високою вирівняністю, однак за фракційним складом є більш дрібнішими в порівнянні з контрольними зразками. Основна їх частка (60-70 \%) отримана сходами сит $\varnothing 3,0$ мм та $\varnothing 1,5$ мм.

Товщина отриманих при досліджуваних режимах ВТО плющених продуктів знаходиться у межах 0,41,1 мм. Плющені продукти отримані із крупи пропареної з вологістю 19,1\% за показником товщчини характе-
} 
ризуються як плющена крупа для якої характерною товщиною є 0,7-0,9 мм. Режим пропарювання крупи при тиску пари 0,15 МПа із вологістю 17,5 \% дозволяє виробляти плющені продукти, які за значенням товщини відповідають контрольним зразкам класичних вівсяних пластівців 0,4-0,9 мм. Зменшення вологості крупи перед пропарюванням до 15,4 \% дозволяе виробляти тонкі пластівиі, значення товщини яких лежить у межах 0,4-0,7 мм.

Окрім товщ⿻ини, міцність зернових пластівціів залежить від масової частки вологи. Для пластівці із більшою вологістю притаманним є більша міцність в порівнянні із продуктом з низькою вологістю. Кінцева вологість вівсяних пластівців нормується регламентом і не повинна перевищувати 12,0\%.

Ключові слова: плющене ядро, овес, пластівці, пропарювання, лущення, режими переробки, хімічний склад.

\section{ЛITЕРАТУРА}

1. Chakraverty, A., Mujumdar, A.S., Raghavan, V., Ramaswamy, H.S. (Eds.) (2003). Handbook of postharvest technology - Cereals, fruits, vegetables, teas and spices. USA Boca Raton: CRC Press.

2. Kent, N.L., Evers, A.D. (1994) Kent's Technology of Cereals, 4th edn., Woodhead Publishing Limited

3. Ryan, L., Thondre, P.S., Henry, C.J.K. (2011) Oat-based breakfast cereals are a rich source of polyphenols and high in antioxidant potential. J Food Compos Anal, 24, 929-934.

4. Правила організації і ведення технологічного процесу на круп'яних заводах. - K., 1998. -164 c.

5. Шутенко, С.I. Технологія круп'яного виробництва: навч. Посібник [Текст] / С.І. Шутенко, С.М. Сои. - К.: Освіта України, 2010. - 272 с.

6. Henry, R., \& Kettlewell, P. (Eds.). (2012). Cereal grain quality. Springer Science \& Business Media.

7. Peltonen-Sainio, P., Kirkkari, A. M., \& Jauhiainen, L. (2004). Characterising strengths, weaknesses, opportunities and threats in producing naked oat as a novel crop for northern growing conditions.

8. Henry, R., \& Kettlewell, P. (Eds.). (2012). Cereal grain quality. Springer Science \& Business Media.

9. Conciatori, A., Stefanis, E. D., Redaelli, R., \& Sgrulletta, D. (2000). Chemical characterization of some kernel traits in naked oat genotypes. Journal of Genetics \& Breeding, 54(4), 299-302.

10. Welch, R. W. (Ed.). (2012). The oat crop: production and utilization. Springer Science \& Business Media.

11. Gajdošová, A., Petruláková, Z., Havrlentová, M., Červená, V., Hozová, B., Šturdík, E., \& Kogan, G. (2007). The content of water-soluble and water-insoluble $\beta$-D-glucans in selected oats and barley varieties. Carbohydrate polymers, 70(1), 46-52.

12. Kaukovirta-Norja, A. Germination: a means to improve the functionality of oat [Text] / A. KaukovirtaNorja, A. Wilhelmson, K. Poutanen // Agricultural and food science. - 2004. - vol. 13, № 1-2. - P. 100112.

13. Hager, A.S. Gluten free beer -A review. [Text] / A.S. Hager, J.P. Taylor, D.M. Waters et al. // Trends in Food Science \& Technology. - 2014. - vol. 36, № 1. - P. $44-54$.

14. Schnitzenbaumer, B. Implementation of commercial oat and sorghum flours in brewing [Text] / B. Schnitzenbaumer, J. Kaspar, J. Titze, et al. // European Food Research and Technology. - 2014. vol. 238, № 3. - P. $515-525$.

\section{Received 12.12.2019 \\ Reviewed 19.01.2020}

$\begin{array}{ll}\text { Revised } & 25.02 .2020 \\ \text { Approved } & 03.03 .2020\end{array}$

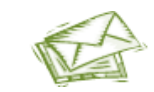

Cite as Vancouver Citation Style

Sots S., Chumachenko Y., Kustov I., Kuzmenko Y. Production of flaked products from naked oats. Physical properties of the flakes. Grain Products and Mixed Fodder's, 2020; 20 (1, 77): 17-22. DOI:

Cite as State Standard of Ukraine 8302:2015

Production of flaked products from naked oats. Physical properties of the flakes. / Sots S. et al. // Grain Products and Mixed Fodder's. 2020. Vol. 20, Issue 1 (77). P. 17-22. DOI:

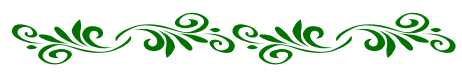

